\title{
Law and the organisational aspects of combating tax crime in Slovak Republic
}

\author{
J. Dworzecki ${ }^{1}$, I. Nowicka ${ }^{2}$ \\ ${ }^{1}$ Academy of the Police Force, \\ 1, Sklabinská st., Bratislava, 83517, Slovak Republic \\ 2 Military University of Land Forces in Wrocław, \\ 109, Czajkowskiego st., Wroclaw, 51147, Poland
}

For citation: Dworzecki, Jacek, Izabela Nowicka. 2020. "Law and the organisational aspects of combating tax crime in Slovak Republic". Vestnik of Saint Petersburg University. Law 3: 693-704. https://doi.org/10.21638/spbu14.2020.311

Fiscal crime in its essence is certainly one of the most dangerous, anti-state phenomena, which constitutes a genuine threat to the entire population of a country. Disturbing opinions on the part of Slovak society regarding the lack of threats to the country's safety, despite fiscal crimes, cannot be ignored without a reaction from the institutions and state organs as well as aware citizens. Taxes, which played one of the most important roles in economic systems throughout history due to the obligatory cash tributes provided to the ruler and later to the state, are now a basic source of income for state budgets and are regarded by many taxpayers as a necessary evil that must be avoided by any means possible. Significant improvement in the level of activities related to the prevention, identification, and detection of tax delicts has been underway since 2012, which involved the creation of the Tax Administration as a result of the merger of two institutions: Customs Administration and Tax Administration. The article clarifies the legal analysis of the provisions supporting institutions in the fight against tax crime and it presents types of tax crimes in the Slovak Penal Code, using statistical data as well as institutions authorized to combat tax crimes in the Slovak Republic.

Keywords: tax crime, combating crime, detection of tax crime, economy, law enforcement, police, administrative institutions, tax fraud, threats, financial intelligence unit.

\section{Introduction}

According to studies of Slovak public opinion, tax avoidance is perceived by a part of society as completely normal and socially acceptable behaviour, which does not carry any risks. It is even considered to be a manifestation of an entrepreneur's individual success. Such perception of public taxation is inherently very dangerous, regardless of whether it represents a certain "heritage" in the way of thinking from the era of "people's democracy", a careless approach of citizens, or their cognisant, calculated, harmful, and antisocial behaviour.

The statutory features of crime based on understating tax liability and the amount of compulsory social, health, and pension insurance are spelled out in article 276 of the Penal Code (hereinafter all cited statutory instruments and court rulings are provided in connection with an inquiry system "Slov-Lex". Accessed June 10, 2020. https://www.slov-lex.sk).

(C) Санкт-Петербургский государственный университет, 2020 


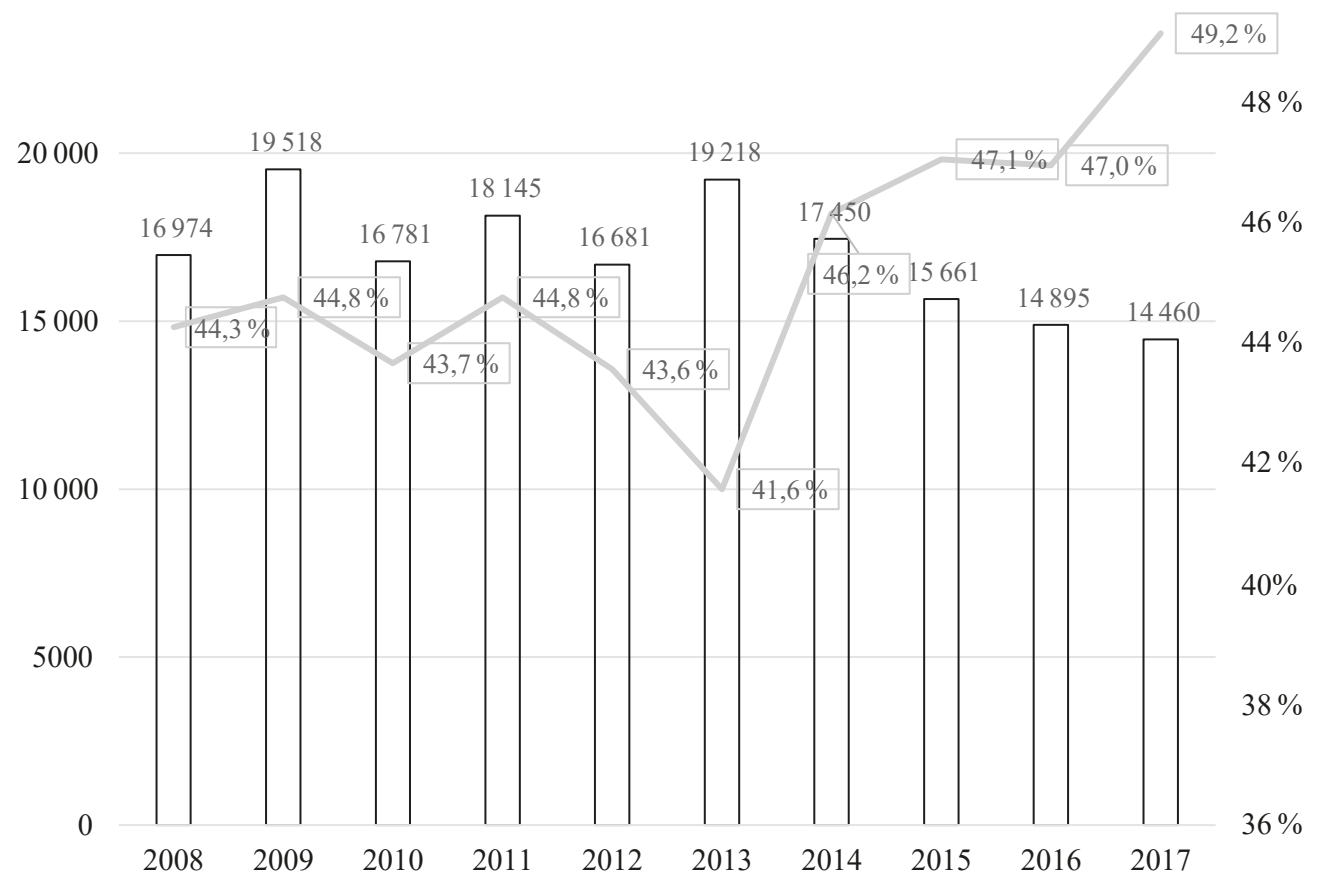

Chart 1. The number of economic crimes and their detection in the Slovak Republic in 2008-2017

S o u r ce: authors' portrayal based on data from the Central Registry of the Police Corps in Banská Bystrica (accessed May 10, 2020. https://www.minv.sk/?statistika-kriminality-v-slovenskej-republike-xml).

From the point of view of tactics applied in detecting (See Chart 1) activities related to tax evasion, the specified crime can be considered as not very complicated. Its essence consists in active, conscious, and insidious acts by the perpetrator aimed at understating the due tax within a defined scope.

The offence of tax and insurance premium evasion implies a conscious procedure where as a result, the perpetrator seeks to reduce the tax or evade the tax liability towards the state treasury. It is an illegal activity by which the perpetrator tries to mislead the tax authorities as to circumstances affecting the amount of his tax liability. The offence of understating the tax liability and the amount of compulsory social, health, and pension premium is usually associated with income tax and a tax on goods and services.

The statutory features of the aforementioned crime in terms of the Code are defined in Chapter II, item V, part III of the Slovak Penal Code in article 276 section 1: Whoever slightly understates a tax liability, mandatory social insurance, public health insurance, or a pension insurance premium shall be liable to a term of imprisonment of one to five years'.

\section{Basic research}

\subsection{Types of tax crimes in the Slovak penal code}

2.1.1. Non-payment of a slight amount of tax and social insurance premiums. The indicated offence is included in article 277 sections 1-4 (chapter II, item V, part III) of the 
Slovak Penal Code. The essence of the perpetrator's act lies in the fact that he commits a fiscal tort consisting of withholding (marginally) and/or not paying a due tax and insurance premiums, which the perpetrator collected or deducted in accordance with the tax code, to a designated recipient. In the case of non-payment of the due tax, the tax authority is the disadvantaged recipient. This offence is interpreted as a special type of tax fraud in the Slovak criminal doctrine. The code definition of the indicated crime, resulting from article 277 section 1 of the Penal Code, reads as follows: Whoever detains or does not pay a small amount of a due tax to a relevant recipient, social insurance, public health insurance, or pension insurance, deducted or collected according to law with the intention of obtaining undue benefits for himself or another person, shall be liable to a term of imprisonment of one to five years.

2.1.2. Tax fraud. Tax fraud is included in article 277 a of the Penal Code (chapter II, item V, part III). It reads as follows: Whoever unlawfully and significantly submits a claim for a tax refund on goods and services or excise duties with the intention of obtaining undue benefits for himself or another person, shall be liable to term of imprisonment of one to five years.

Tax fraud, classified as a crime, can be committed in the dimension of the so-called excess damage. This is evidenced by the crime being at least ten times the amount of 266 euros (i. e. more than 2660 euros).

The State Treasury has in interest in the crime of tax fraud due to the right to tax goods, services, and excise duties. The signs of this criminal act include the actions taken by the perpetrator applying for an undue tax refund, in particular the tax on goods and services.

2.1.3. Non-payment of tax and social insurance premiums. The statutory characteristics of the offence for non-payment of tax and insurance premiums are included in article 278 section 1 of the Penal Code (chapter II, item V, part III), the content of which states: Whoever does not pay a significant amount of due tax, social insurance, health insurance, or pension insurance premiums shall be liable to a term of imprisonment of up to three years.

This article of the Penal Code is also in the interest of the State Treasury to secure timely payment of due tax, as well as social insurance, public health insurance, and pension insurance premiums. The indicated provision sanctions all taxpayers who do not fulfil their obligations under the relevant tax law.

2.1.4. Hindering activities of tax authorities. This offence is included in article 278a sections 1-3 of the Slovak Penal Code (chapter II, item V, part III).

The subject of the analysed crime is the activity of Slovak tax authorities subject to legal protection and the statutory duty of taxpayers, correlated with it, to fulfil all orders, recommendations, etc. issued by the indicated institutions (Ivor, Polák, Záhora 2016, 281).

The crime of hindering the activities of tax administration authorities is an intentional act. Therefore, it is necessary for criminal proceedings to prove that the perpetrator acted deliberately. If the perpetrator is suspected of failing to fulfil his statutory duty, it is indispensable to prove in the course of criminal proceedings that he was acquainted with this duty, but deliberately failed to obey it. The practice of criminal proceedings indicates that the perpetrator's awareness of fulfilling the statutory duty towards the tax administration is very difficult to prove. 


\subsubsection{Infringement of regulations concerning security controls for the labelling of}

goods. Crime regarding the counterfeiting or modifying of, among others, excise marks, has been included in article 279, sections 1-3 of the Slovak Penal Code (chapter II, item V, part III). The application of control protections (including excise and technical) for labelling certain goods, such as alcohol, tobacco, tobacco products, and precious metals, is an action designed to protect the key economic interests of the state, including, inter alia, the regular inflow to the State budget, market protection, and consumer protection.

The term 'control stamp' should be understood as a stamp on which the price of cigarettes is indicated and meets the formal requirements of excise labelling in accordance with Act No. 106 of the National Council of the Slovak Republic of 3 February 2004 on excise duties on tobacco products with later amendments. The control strip intended for marking consumer packaging is a band that meets formal requirements in accordance with Act No. 530 of the National Council of the Slovak Republic of 30 November 2011 on excise duties on alcoholic beverages with later amendments. The control strip should also be understood as a band used for consumer labelling of tobacco packaging, tobacco products, and alcoholic beverages. Consumer packaging is a closed package intended for direct human consumption. In addition, other control protections used in Slovakia to mark goods include labelling, for example, in relation to viticulture and wine production, copyright or assay law.

2.1.6. Illegal production of spirit. The statutory characteristics of the offence of the illegal production of spirit are included in article 253 sections 1-2 of the Penal Code (chapter II, item V, part I). The indicated paragraph reads: Who without permission produces a higher amount of spirit or who stores or puts into circulation the produced spirit in a larger quantity without permission, if at the convergence of offences he did not commit a crime with a more severe punishment, shall be liable to a term of imprisonment of up to two years. The one who illegally constructs or stores the device for the production of spirit also bears criminal liability as described in section 1.

The offence concerned denotes a punishable act strictly related to tax evasion in regard to the excise duty on alcoholic beverages or spirit. In the context of committing the aforementioned crime, a special place is occupied by the Act of the National Council of the Slovak Republic No. 467 of July 2, 2002 on the production of spirits and its introduction to the market.

\subsection{Institutions authorised to combat tax crime in the republic of Slovakia}

2.2.1. The police corps of the Slovak Republic. Two groups function in the internal security system of the Slovak Republic. The first group includes state organizations, while the second group consists of entities with a non-state (local government, private) character (See Diagram 1). At the ministerial level, state organizations are subject to a particular ministry competent for their specificity of activities, headed by the minister, and also to central bodies, such as the President of the Police Corps and institutions located at the lower (provincial) or local (district) levels of state administration. The activity of all state organizations is defined and limited by separate legal acts and trade union acts, e. g. regulations, orders and decisions. Persons employed in these organizations establish a business relationship with the state as an officer or civil servant of a specific department of the state administration. 


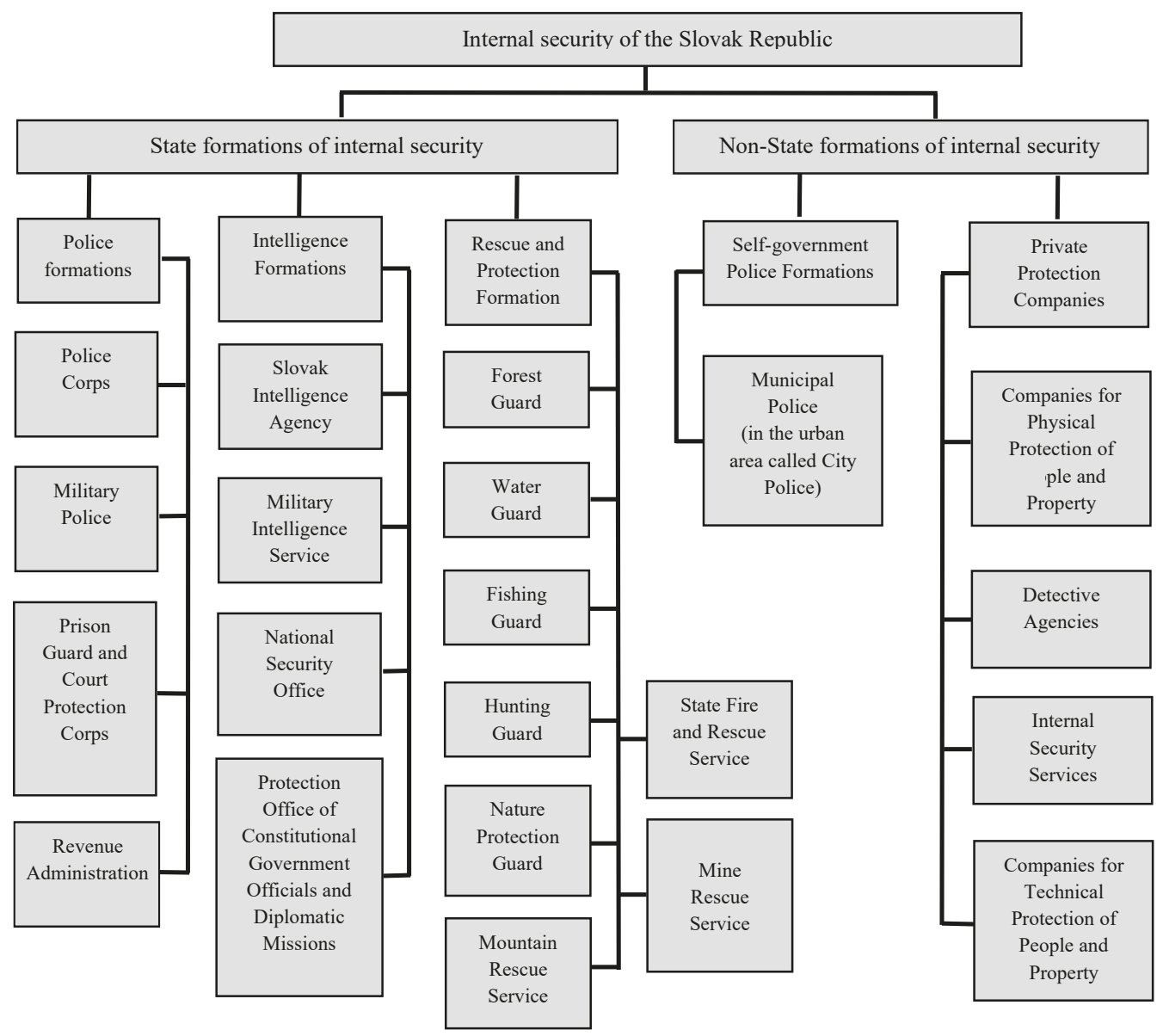

Diagram 1. Formations implementing tasks in the area of internal security of the Slovak Republic (as of 10.12.2018)

Source: Authors' portrayal on the basis of: https://www.minv.sk; https://www.justice.gov.sk; https://www.nbu.gov.sk; https://www.mod.gov.sk, https://mp.mil.sk, https://www.zvjs.sk/en, https://www. financnasprava.sk/sk/titulna-stranka, https://www.sis.gov.sk, http://vs.mosr.sk, https://www.hzs.sk, https:// www.minv.sk/?hasici-zachranari, https://banskazachranka.sk.

Article 1 point 1 of Act No. 171/93, characterises the Police Corps as "armed security corps implementing tasks in the area of public safety and order, combating all forms of crime, including organised and international crime and performing other tasks in the area of security, resulting from the international obligations that the Slovak Republic adopted in this respect".

The Police Corps is controlled by the National Council and the Government of the Slovak Republic. This organization operates within the limits of the applicable law, based on the provisions of the Constitution, general laws, and other union legal acts, as well as on the basis of international agreements ratified by Slovakia.

The management of the organisational units of the Corps and organisational units of the Police Corps Presidium in Bratislava (an organisational unit corresponding in substance to the National Police Headquarters in Warsaw) is subordinate to the President of 
the Slovak Republic Police Corps, who is appointed and dismissed by the Minister of the Interior (See Diagram 2). The President of the Police Corps is the central body of government administration, competent in matters of protecting civil security, maintaining public safety, and ensuring order in the territory of the Slovak Republic (Dworzecki 2013).

The National Criminal Agency of the Police Corps Presidium (hereinafter referred to as NAKA) is a specialised, independent (in the substantive, financial and tactical scope), and elite organisational unit of the Police Corps, designed to combat the most serious forms of crime, including organised crime. It was established on December 1, 2012 as a result of the merger of two offices located in the Police Corps Presidium, i. e. the Office to combat Corruption and the Office to combat Organised Crime. The appointment of the NAKA enabled better coordination of actions, undertaken together with the prosecutor's office, against organised criminal associations, and contributed to the elimination of the competence duality resulting from the functioning of the Presidium's organisational units, which repeatedly, independently of one another, carried out operational and fact-finding activities and inquiry-investigation operations focused around the same issue. In addition, the reduction of logistical costs has made it possible to improve mobility and increase the operating range of the new structure. The Agency's Director, within the substantive and organisational scope, reports directly to the President of the Police Corps.

2.2.2. The unit for combating economic crime of the national criminal agency of the police corps presidium of the Slovak Republic. The Unit to combat Economic Crime is a specialised component of the National Criminal Agency of the Presidium of the Police Corps. Operational fact-finding as well as inquiry investigation tasks in the field of disclosure, detection, and prosecution of offenders of an economic nature are conducted by the unit. Due to the specificity and multilateral nature of economic crime and threats to state security correlated with it, the Unit to combat Economic Crime NAKA, also performs supervisory and coordination tasks in relation to the segments of the criminal division of the Police Corps, whose officers in field units deal with this form of crime.

The Unit fighting against Economic Crime NAKA cooperates closely with bodies authorised to conduct proceedings in cases of fiscal crimes and abuses. It also undertakes detection initiatives in the field of economic crime, including international activities under the auspices of the European Union, e. g. the EMPACT cooperation platform (European Multidisciplinary Platform Against Criminal Threats) and the MTIC (Missing trader intra-Community fraud) platform (activities to combat intra-Community tax fraud based on an unjustified refund of input VAT) as well as in projects coordinated by Europol.

\subsubsection{Financial intelligence unit of the national criminal agency of the police} corps presidium of the Slovak Republic. The Financial Intelligence Unit (hereinafter referred to as FIU) of the National Criminal Agency of the Police Corps Presidium deals, among other things, with the analysis of information on the illegal origin of property, including property valuation, sources of its origin, and methods of property acquisition. In addition, the officers of FIU conduct activities to prevent and detect cases of money 'laundering' and combat all identified mechanisms of financing activities of a terrorist nature. Moreover, the spectrum of interest of FIU includes all tax crimes and determinants that may lead to this kind of criminal behaviour.

The unit has the status of an institution with control powers, in relation to the units listed in article 5 of the Act on the protection against legalisation of income from criminal activity and financing of terrorism. 


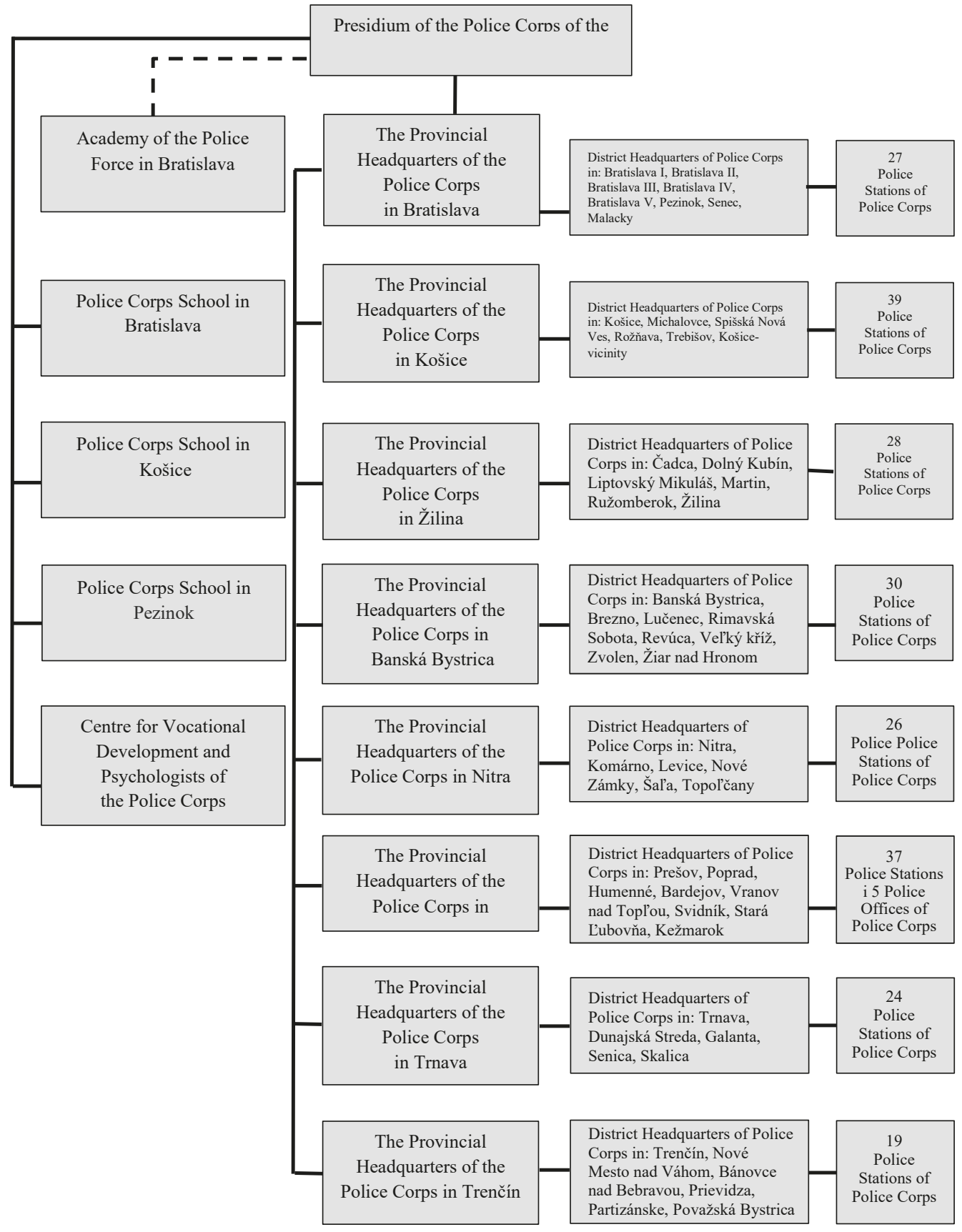

- - - cooperation in the coordination of educational content at officer's courses and supervising officers of the Police Corps employed in the Police Corps Academy in didactic and logistic positions

Diagram 2. Organisational chart of the Police Corps of the Slovak Republic (as of 10.07.2018)

S o u r c e: Authors' portrayal based on https://www.minv.sk (accessed 10.02.2020). 
In addition, legal acts on the basis of which police officers from FIU take action include Act No. 101 of the National Council of the Slovak Republic of 4 March 2010 on the proving of the origin of property and Act No. 171 of the National Council of the Slovak Republic of June 6, 1993 on the Police Corps, and other legal regulations. The methods and forms of operational and fact-finding work, applied by FIU as part of the implemented activities, are defined in many internal acts, which, moreover, specify both the areas of interest of the FIU and specify the subject of the undertaken control initiatives.

Much information used in the activities of FIU officers comes from police databases, from IT resources collected by other state administration institutions, and from public sources (including trade registers, concession registers, etc.). Moreover, based on the rules of cooperation between state administration entities and local governments applicable in the Slovak Republic, a lot of information is obtained on the basis of a written request regarding legal (inter-institutional) assistance. If, in the course of conducted operations, officers receive information that the assets of the controlled entity (or its part) are located outside the country, the Financial Intelligence Unit undertakes activities aimed at securing the property, through its division - the Department of Property Control and in cooperation with foreign entities, e. g. Asset Recovery Offices (hereinafter to as ARO) or institutions operating in the CARIN network (Camden Assets Recovery Interagency Network) ${ }^{1}$.

Since 2008, on the basis of the provisions of the Council Decision 2007/845/JHA of 6 December 2007 concerning cooperation between Asset Recovery Offices in EU Member States in the field of detection and identification of benefits resulting from crime or other property related to crime, the Financial Intelligence Unit NAKA has been responsible for undertaking such activities within the territory of the Slovak Republic.

It should be noted that the use of information obtained as part of cooperation with the ARO network and concerning the property of a person or controlled entity, where the basis for their activities is the Council Framework Decision 2006/960/JHA of 18 December 2006 on simplifying the exchange of information and intelligence data between law enforcement authorities of EU Member States, is quite problematic, especially in the light of the selected passages of Act No. 101 of the National Council of the Slovak Republic of 4 March 2010 on proving the origin of property. The exchange or obtainment of information about the assets of controlled entities may be based on the abovementioned EU Council Framework Decision only in a situation where actions have already been taken as part of criminal prosecution, and it is not allowed in any other case, e. g. conducting explanatory actions. It happens that foreign ARO offices informed about actions regarding control, undertaken by the Financial Intelligence Unit NAKA whose aims are based on the dispositions of Act No. 101/2010 to determine the assets of an entity remaining in the Slovak party's interest, reject the request for the provision of relevant information (Dworzecki, Stieranka 2015).

${ }^{1}$ Inter-Agency Camden Recovery Network (CARIN), it is an informal network of experts and practitioners involved in disclosing, securing and confiscating assets coming from crime. This is an inter-agency network and therefore each member state of this organisation has its representative in the form of an officer from law enforcement bodies and another representative of a given country institutions being part of the structure of justice (prosecutor, investigating magistrate, etc., depending on the legal system). People representing member states in CARIN are called 'national contact points'. All representatives must use English, which is a working language on the web. You can connect with each contact point by phone or via email, thanks to the contact list available to all CARIN participants. The goal of CARIN is to increase the efficiency of Member States' efforts to deprive criminals of their illegal income. The Financial Intelligence Unit NAKA has been a member of the network since 2004 . 
It should be emphasised that not only specialised organisational units of the Police Corps deal with combating economic crime, including tax crime. Operational and factfinding operations as well as inquiry and investigation activities are conducted across the country by over seven thousand police officers. These are officers of the criminal service carrying out their tasks in organisational units from provincial and district headquarters and at police stations of the Police Corps.

2.2.4. Revenue administration. The Revenue Administration was established on January 1, 2012 as a result of the merger of two institutions, i. e. the Customs Administration and Tax Administration. The establishment of the Revenue Administration was initiated by changes that were successively introduced in the country, in accordance with the Resolution of the Slovak Republic Government No. 285 of 7 May 2008 on the Concept of Tax and Customs Administration Reform, to unify the collection of taxes, customs duties, and insurance premiums.

The Revenue Administration implements tasks resulting from several legal acts including, inter alia, Act No. 333 of the National Council of the Slovak Republic of 14 September 2011 on state administration bodies in the area of taxes, charges, and duties; Act No. 479 of the National Council of the Slovak Republic of 22 October 2009 on state administration bodies in the area of taxes and charges; Act No. 652 of the National Council of the Slovak Republic of October 26, 2004 on state administration bodies in the area of duties, and also based on agreements and ratified international contracts.

The Revenue Administration is composed of local organisational units: Customs Offices (9), Tax Offices (9), Tax Office Departments (39), Customs Office Departments (62), Technical Stations of Customs Offices (18), Contact Points of Tax Offices (24) and the Criminal Office of Revenue Administration and the Directorate of Revenue Administration with a registered seat in Banská Bystrica (See Diagram 3).

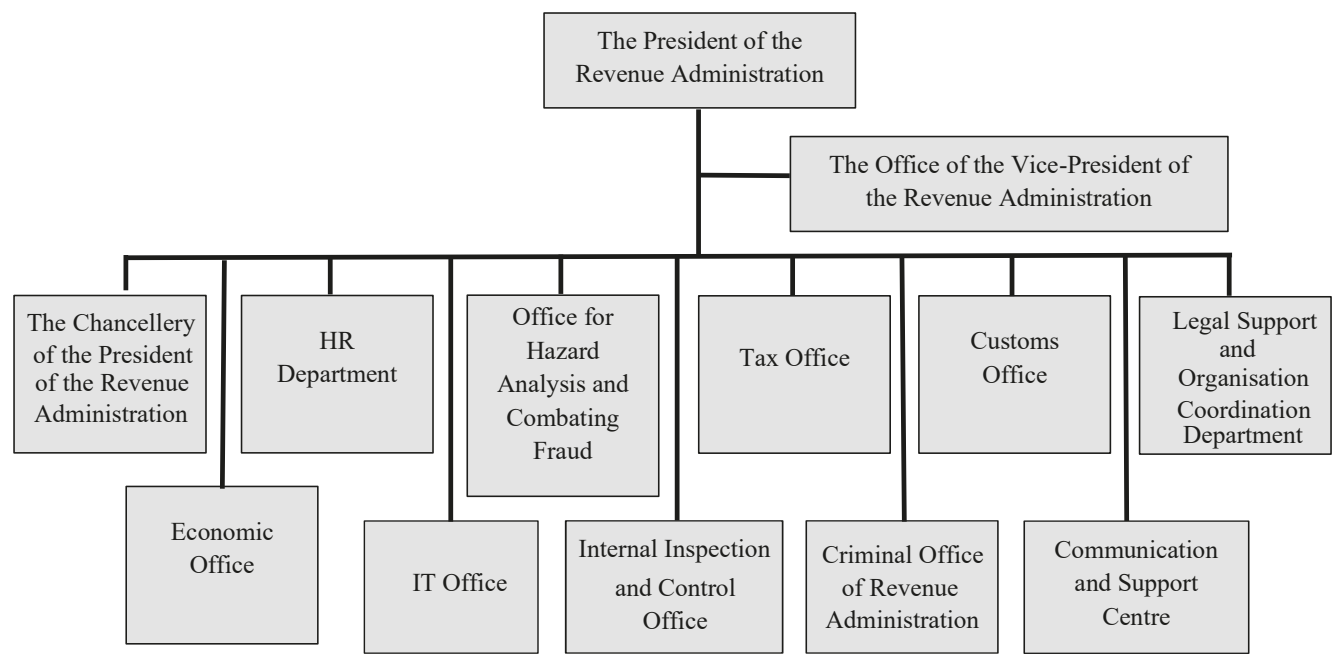

Diagram 3. Organisational structure of the Revenue Administration Directorate in Banská Bystrica (as of 28.10.2018)

S o u r ce: Authors' portrayal based on the Organisational Regulations of the Revenue Administration Directorate in Banská Bystrica (a copy in the authors' collection) (accessed December 10, 2019. https:// www.financnasprava.sk/sk/titulna-stranka). 


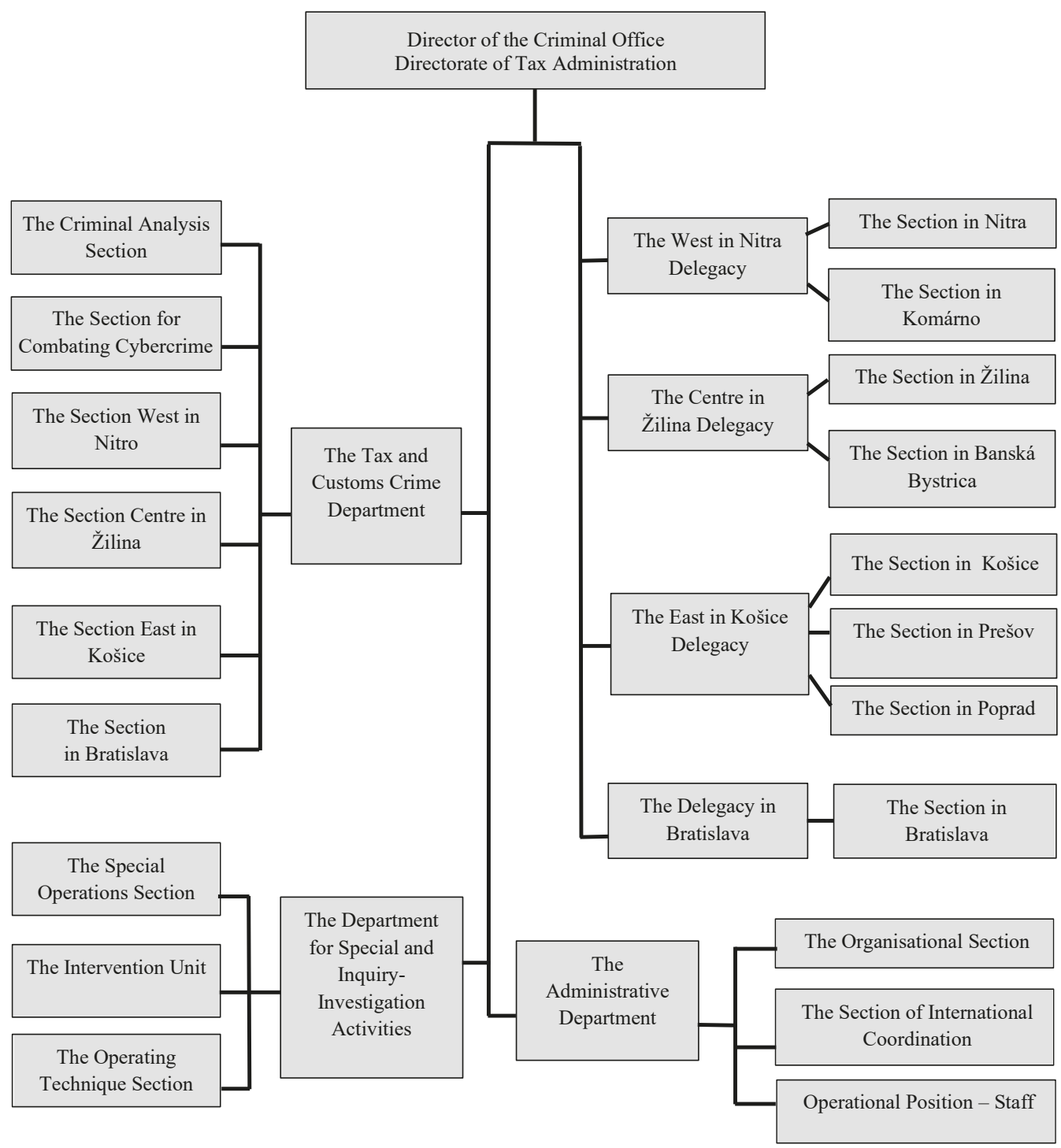

Diagram 4. Organisational structure of the Criminal Office of the Revenue Administration with its registered office in Bratislava (as of 28.10.2018)

So u r ce: Authors' depiction based on the Organisational Regulations of the Directorate of Revenue Administration in Banská Bystrica (a copy in the authors' collection) (accessed December 10, 2019. https:// www.financnasprava.sk/sk/titulna-stranka).

The Revenue Administration is headed by the president (with one deputy) who is appointed and dismissed by the Minister of Finance. The Revenue Administration employs both civilian employees and customs officers. Currently, the entire institution consists of more than nine thousand people. The main task of the Revenue Administration is to oversee the effective collection of duties and taxes, constituting the basic income of the state budget, protection of the economic interests of the Slovak Republic, and control of budget expenditure. 
In terms of advising, the Director of the Revenue Administration is supported by the Consultative Council, whose task is to, inter alia, analyse currently used customs, tax or fiscal solutions, search for new models of cooperation between the administration and government, self-government, and social institutions or legal entities. The meetings, organised on a quarterly basis, are attended by permanent members of the Consultative Council and invited guests representing various domestic and foreign customs and tax institutions.

In structural terms, the Directorate of the Revenue Administration consists of offices, sections, divisions, bureaus, the Criminal Office of Revenue Administration and the Chancellery of the President of Revenue Administration

Thanks to its statutory activity, the Revenue Administration added EUR 3,7 billion to the state treasury through the elimination of tax crimes, which facilitated the reduction of a budget deficit in 2017 from 41 to $26 \%$.

2.2.5. The criminal office of the revenue administration. The Criminal Office of the Revenue Administration based in Bratislava is a specialised investigative unit of the Revenue Administration Directorate, dedicated to combating customs and tax crimes (See Diagram 4). The Office is headed by the director, appointed and dismissed by the President of the Revenue Administration to whom he is directly responsible. The tasks and powers of the Revenue Administration Criminal Office are set out in article 5 of Act No. 333 of the National Council of the Slovak Republic of 14 September 2011 on state administration bodies in the area of taxes, charges, and duties.

The Criminal Office was created on January 1, 2012 with the establishment of the Revenue Administration and took over the personal, technical, and material resources of its substantive predecessor, the Criminal Office of the Customs Service that operated from January 1, 2005 under the Act No. 652 of the National Council of the Slovak Republic of October 26, 2004 on state administration bodies in the area of customs. The activities of about 400 customs officers employed at the Office's headquarters and its field units are focused on customs and tax offences, economic crimes, illegal distribution of narcotic drugs and psychoactive substances or precursors used in their production, unauthorised trade in radioactive materials or particularly harmful and dangerous products, unauthorised trade in endangered species of fauna and flora, and the trade of antiques.

The Criminal Office of Revenue Administration cooperates closely with the Police Corps and other Slovak formations of internal security as well as with its principal foreign counterparts. Service in the Office, especially in operational and fact-finding units, is perceived by officers as elite, which results in a very large number of volunteers, of whom only a few (on average $2 \%$ ) pass the selection procedure.

\section{Conclusions}

Crime has accompanied humanity since the beginning of its existence, and the task of contemporary societies is to constructively and consistently solve problems that appear on the path of their evolutionary development. Unambiguously, negative aspects of the functioning of human communities, manifesting themselves both in the form of common crimes and those with the most serious character, constitute a direct threat to every society. 
From the beginning of the political transformation until the middle of the first decade of the $21^{\text {st }}$ century, an increase in the number of crimes was apparent in the countries of the former communist bloc. It was no different in the Slovak Republic, where the highest crime rate in the first decade of the new century was recorded in 2004.

Thanks to the professionalism and multiethnic cooperation of the Slovak institutions, as well as the modernisation of available instruments and the improvement of detection methods, it is possible to effectively combat economic crimes, including tax and customs offences (See Chart 1). At the same time, in the minds of all representatives of the Slovak tax and law enforcement agencies, the conviction remains that institutions established to prevent and combat any form of crime must receive clear and multifaceted support from society, without which the undertaken actions will be doomed to failure.

\section{References}

Dworzecki, Jacek. 2013. "Korpus Policji w systemie bezpieczeństwa wewnętrznego Republiki Słowackiej”. Wybrane problemy bezpieczeństwa. Aspekty społeczno-ideologiczne, ed. by Andrzej Urbanek, 133-170. Słupsk, Akademia Pomorska.

Dworzecki, Jacek, Josef Stieranka. 2015. "Wybrane możliwości identyfikacji (detekcji) deliktów skarbowych w realiach Republiki Słowackiej”. Zeszyty Naukowe WSFiP 1: 160-184.

Ivor, Jaroslav, Peter Polák, Jozef Záhora. 2016. Trestné právo hmotné I. Všeobecná čast. Bratislava, Wolters Kluwer.

Authors'information:

Jacek Dworzecki - Professor; jacekdworzecki@o2.pl

Izabela Nowicka - Associate Professor; ibiza.n@wp.pl 